\author{
IrAs Exansion
}

\title{
Wood to Energy: Woody Biomass Conversion Technologies ${ }^{1}$
}

\author{
Jessica Tomasello, Lauren McDonell, Martha C. Monroe, and Annie Oxarart ${ }^{2}$
}

A variety of technologies can transform wood into energy for residential, commercial, and industrial uses. Wood-to-energy systems can produce anywhere from less than 1 megawatt (MW) to more than 100 MW of power and can use wood exclusively or in combination with other fuels, such as coal or natural gas. This energy can be used to generate electricity; heat buildings with water, steam, or air (space heat); produce steam for industrial processes; or power vehicles and machinery. All of the processes involve breaking down the cellulose in wood to release the energy it contains. See the Wood to Energy Fact Sheet, Systems that Convert Wood into Energy, for more information. All of the Wood to Energy materials can be found at http://edis.ifas.ufl.edu under Woody Biomass and at http://www.interfacesouth.org/woodybiomass.

In order to understand energy production, it is important to know how we measure energy. Units of energy used in the United States are British thermal units (Btu), kilowatt ( $\mathrm{kW})$, kilowatt hour ( $\mathrm{kWh}$ ), and megawatt (MW). See Box 1 for more information on energy units.

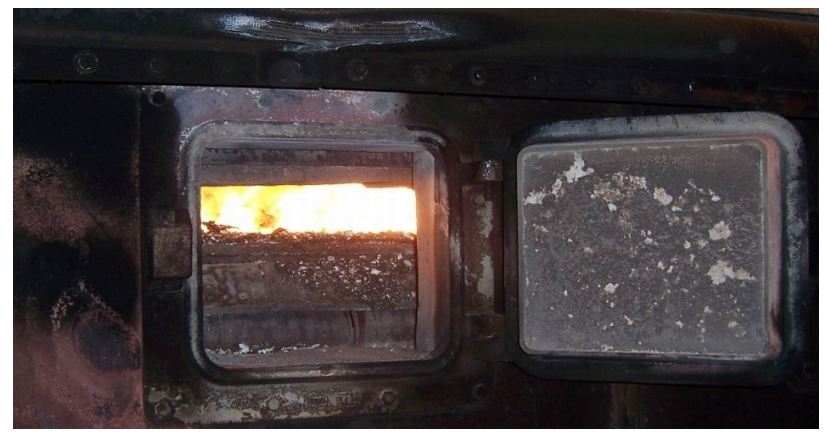

Figure 1. Wood can be burned in a boiler to heat water and generate steam. Credits: Lauren McDonell

\section{Using Wood in its Solid Form}

The simplest way to obtain energy from wood is through a process called "direct combustion" (in other words, by burning it). Energy from burning wood can produce power, electricity, or heat. To produce power, wood can be burned in a boiler, a large combustion chamber, to heat water and generate steam (Figure 1). In some cases, this steam is used directly to power machines or to heat buildings. Some schools, for example, run steam through a system of pipes to heat classrooms. See the Wood to Energy case studies, Burning Sawdust for Heat and Power and Wood Power Heats a Public School, for examples of schools that use wood for heat. Some

1. This document is FOR222, one of a series of the School of Forest Resources and Conservation Department, Florida Cooperative Extension Service, Institute of Food and Agricultural Sciences, University of Florida. Original publication date June 2009. Visit the EDIS Web Site at http://edis.ifas.ufl.edu.

2. Jessica Tomasello, outreach research associate; Lauren McDonell, outreach research associate; Martha C. Monroe, professor; and Annie Oxarart, outreach research associate, School of Forest Resources and Conservation, University of Florida

The Institute of Food and Agricultural Sciences (IFAS) is an Equal Opportunity Institution authorized to provide research, educational information and other services only to individuals and institutions that function with non-discrimination with respect to race, creed, color, religion, age, disability, sex, sexual orientation, marital status, national origin, political opinions or affiliations. U.S. Department of Agriculture, Cooperative Extension Service, University of Florida, IFAS, Florida A. \& M. University Cooperative Extension Program, and Boards of County Commissioners Cooperating. Millie Ferrer, Interim Dean 
hospitals also burn wood to produce steam for sterilizing equipment and powering machines. Other industries drive machinery with steam.

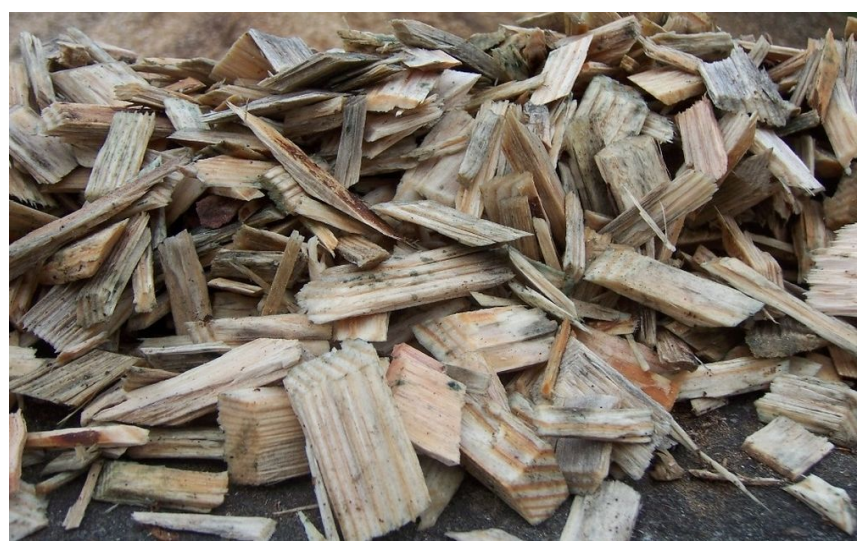

Figure 2. Most facilities use wood particles of consistent size, such as wood chips. Credits: Lauren McDonell

In addition, steam can be used to turn large, rotating engines called turbines, which generate electricity. This electricity can be used onsite by industries to power machinery, or it can be sold to the power grid. Some facilities do both-steam first turns a turbine and then is used for heat. This is called co-generation because two forms of energy are generated from one process.

When wood is used in power plants, it can be burned alone or in combination with coal or other fuels; burning two fuels together is called co-firing. See the Wood to Energy case study, Co-firing with Wood and Switchgrass, for an example of a co-firing power facility.

Because it is more efficient to burn wood pieces that are the same size and have similar moisture content, most facilities use wood chips, wood pellets, or saw dust (Figure 2). Wood chips are typically 5 to 50 millimeters $(\mathrm{mm})$ long, and longer than they are thick or wide; wood pellets, made from compressed sawdust, range from 5 to $30 \mathrm{~mm}$ long; and sawdust is the smallest at 1 to $5 \mathrm{~mm}$ (Florida Agriculture Organization 2004).

Combustion systems can use different forms of wood, including split fuel wood (traditional firewood), whole trees, wood chips, wood pellets, waste wood from forest product production processes, and charcoal briquettes. Some of the wood-burning units can also use other types of fuel such as oil or natural gas in combination with wood or electricity from the power grid. Wood can also be burned to produce heat using woodstoves, fireplaces, pellet stoves, or boiler systems. These systems can be located inside or outside buildings. For more information, see the Wood to Energy Fact Sheet, Small Heating Units.

\section{Converting Wood into Gas}

Woody biomass can be converted into a synthesis gas (syngas) through the process of gasification. It can be made into biogas through the process of anaerobic digestion.

1. Gasification: exposing wood to extremely high temperatures $\left(900-1,200^{\circ} \mathrm{C}\right)$ and pressure in a low oxygen environment can produce syngas - a gas made up of carbon dioxide, carbon monoxide, and hydrogen. Syngas is combustible and can be used as a fuel source.

2. Anaerobic digestion: exposing wood to certain bacteria in the absence of oxygen and under other controlled conditions can produce biogas, a type of fuel produced from biomass materials.

In both processes, a gas is produced as the cellulose is broken down. Syngas and biogas can be used like natural gas for cooking, heating water or buildings, or producing electricity.

\section{Converting Wood into Liquid Oil}

Wood can also be made into a type of liquid oil, also called bio-oil, by heating it quickly to a high temperature in the absence of oxygen. This process is called fast pyrolysis. In addition to producing liquid oil, this process produces char and a combustible syngas.

Bio-oil can be burned in boilers to heat buildings or in generators to produce electricity. Since the bio-oil contains a much higher amount of energy per unit volume than wood, it is easier and cheaper to transport than wood. The pyrolysis syngas, as mentioned earlier, can be used much like natural gas. The char can be processed into briquettes for grilling 
and can also be used to purify metals and as an additive to fertilizer.

\section{Converting Wood into Transportation Fuels}

Wood can also be used to produce transportation fuels, such as ethanol, methanol, or biodiesel. Ethanol is produced through a process called fermentation in which wood is exposed to microorganisms. As these microorganisms decompose the wood, enzymes are produced. These enzymes trigger a chemical reaction that exposes and breaks down the sugars in the wood. Certain microbes can then be added to the sugar solutions to convert them into ethanol, a colorless alcohol, and other byproducts. Once processed, ethanol can be used in combination with gasoline to make E-10 or E-85 to power vehicles equipped to burn it. E-10 contains 90 percent gasoline and 10 percent ethanol and can be used in most modern vehicles; E-85 contains 15 percent gasoline and 85 percent ethanol and can be used in engines modified to run on higher concentrations of ethanol, such as flexible-fuel vehicles. Research is progressing quickly to make this process feasible on a large scale.

Another liquid, methanol, can be produced from woody biomass. When woody biomass is gasified, the resulting gas can be converted to a liquid. This is one method of producing methanol. Methanol can be used to fuel vehicles or to produce other chemical products. Currently, most methanol is produced using natural gas.

Additionally, biodiesel is a liquid fuel that can be used to power machinery and vehicles. In a process called alcoholysis, oils extracted from wood are combined with alcohol and a catalyst to produce a renewable diesel fuel. Thanks to relatively new technological breakthroughs, woody biomass can provide the substances needed to manufacture renewable diesel fuels on a larger scale.

\section{Summary}

There are many strategies that can harness wood's energy for a variety of uses, making wood a versatile energy resource. With existing technology, wood energy can produce electricity, space heat, power, or transportation fuels on a small scale.
Researchers are working to increase efficiency and flexibility by creating new technologies for converting wood to energy. These new technologies are evaluated based on efficiency (obtaining the most energy output for the least energy input), environmental emissions (air, water, noise, and heat), and public acceptance.

Additional Wood to Energy fact sheets, community economic profiles, and case studies can be accessed at http://edis.ifas.ufl.edu under Woody Biomass or at http://www.interfacesouth.org/woodybiomass. Also, visit the Forest Bioenergy Web site, http://www.forestbioenergy.net, to access a number of other bioenergy resources.

\section{References}

Food and Agriculture Organization (FAO). 2004. Unified bioenergy terminology: Definitions of main terms.

ftp://ftp.fao.org/docrep/fao/007/j4504e/j4504e00.pdf (accessed May 1, 2008).

U.S. Energy Information Administration (EIA). 2006. Apples, oranges, and Btu. http://www.eia.doe.gov/neic/infosheets/apples.html (accessed June 13, 2008). 
Box 1. Common energy measurement units in the U.S.

\begin{tabular}{l} 
Energy Units \\
British thermal unit (Btu): the amount of heat required to increase the temperature of \\
1 pound of water 1 degree Fahrenheit. 1 Btu is approximately equal to the energy \\
released in the burning of a match (U.S. EIA, 2006). \\
Kilowatt (kW): the rate of electrical power output, which is equal to 1000 watts. \\
(A watt (w) is the basic measurement of electricity used in the United States.) \\
Kilowatt hour (kWh): a measure of energy consumption, equal to 1,000 watts over a \\
one-hour period. The kWh is what your utility provider measures to determine how \\
much electricity your household uses. \\
Megawatt (MW): a measure of power plant electricity generation capacity, which is \\
equal to 1,000,000 watts. \\
$\qquad \begin{array}{c}1 \text { million Btu }=\text { approximately } 8 \text { gallons of gasoline } \\
1 \text { billion Btu }=\text { all the electricity that } 300 \text { average U.S. } \\
\text { households consume in one month. } \\
1 \text { trillion Btu }=500 \text { railroad cars of coal, each weighing } 100 \text { tons } \\
1 \text { quadrillion Btu = } 172 \text { million barrels of crude oil } \\
\text { (U.S. EIA 2006) }\end{array}$ \\
\hline \hline
\end{tabular}

